\title{
The Allocation of Power between Religious and Secular Authorities in Egypt
}

\author{
Adel Omar Sherif
}

\begin{abstract}
The struggle over religious authority in organized societies, and hence the allocation of power between religious and secular authorities in the modern state, is at the heart of constitutional law. In Egypt, the Supreme Constitutional Court, one of the oldest institutions endowed with constitutional review powers in the region of the Middle East and North Africa, has developed over the past decades an interpretation of the pertinent Constitutional provisions. The chapter, referring to three landmark rulings of the Supreme Constitutional Court, is discussing who should have the final role on sharia and whether secular authorities have the legitimacy to be allocated such a power. The author illustrates the complexity of the interpretation of the constitutional articles, and highlights the Supreme Constitutional Court's stance not to allocate supremacy of a particular constitutional provision over the other ones, but instead to consider all the provisions as an interrelated organic unit. As the institution exclusively endowed with power to interpret the Constitution, it is the Supreme Constitutional Court to have the final word.
\end{abstract}

Who has the Final Word on sharia in Egypt? The Supreme Constitutional Court, Al-Azhar, or Dar al-Ifta'

\section{Introduction: Religion v. state - A deep-rooted struggle}

The struggle over religious authority in organized communities is as old as the emergence of these communities themselves. History has shown us how contentious and bloody the tension between religious clergies, on one hand, and the rulers on the other, has always been, wherever and whenever the two parties competed with each other over assuming power in any given society. In ancient civilizations, as in ancient Egypt 
for example, thousands of years ago, the existence of a God was held inherently unquestionable. Religious aspiration was clearly manifested in the lives of the people in every way; hence, definitely influenced the form of their governance systems. God was there to tell people what they should do and what they should not. Therefore, people always believed that their worshiping of a God would help them getting a divine earthly support throughout the journey of their lives followed by a heavenly reward in the hereafter. At these ancient times, the clergies, being keen on controlling all powers, including political power, portrayed themselves as a sole road to God and salvation. Since people had a lot of belief in the clergies and always honored them, the clergies usually successfully managed to recruit the supreme ruler of the land, or the King, to their side, and even to position him as a God himself in order for him to gain the support of the subjects. There were not many options available before the King to follow if he wished his reign to be peaceful and uninterrupted. The price he had to pay, therefore, was to establish his integration within, or at least alliance with, the religious institution as a way of ensuring his divinity and legitimacy. The process of subjecting one team to the other had never been that easy, but rather a catastrophic one marked by wars and bloodshed. But in all cases, religion was always there, presenting itself as a key-factor in ruling ancient societies.

One way or the other history continued to show us, chronologically, that the ancient Egyptian model had been similarly adopted by many sequential civilizations and nations. Indeed, there was a turning point in modern history with the arrival of secularism and separation between state and religion. Nonetheless, the influence of religion is still there at different levels, not only in these states that are constructed on religious basis, but also in those states that explicitly encourage such separation. Therefore, it becomes necessary, with the domination of a religious orientation in any given society, to identify those figures or institutions that are authorized to tell us what religion informs us and how religious rules should be decided, then implemented. Only by this, the transparency of the law and order would be guaranteed and maintained.

\section{Who decides the law in Muslim communities? An ongoing struggle}

In that sense, in a Muslim dominated society, the question of law, as who has the power to decide what the law is, presents itself as a serious issue of immense importance. It is all about revealing the Will of God, by competent figures, mujtahedin, in a way that is consistent with recog- 
nized Islamic norms. Since its inception in Medina in the year $622 \mathrm{CE}$, and throughout the subsequent few centuries, during the golden age and spreading over of Islamic rule, the centralization of power in the hands of the Khalifa, who was usually himself a competent mujtahid, there had been not much controversy over this issue due to the existing unification, at that time, of religion and state. But at a later stage, when Islamic states or societies gradually became more considerate of politics and the power of ruling itself regardless of the compatibility of exercising this power within Islamic norms, the struggle over religious authority became evident. Such struggle assumes that political authority has invaded the realm reserved for mujtahedin, or the religious authority, by asserting its power to decide the law, either solely or in some form of collaboration between them. The modern form of Islamic state reflects this struggle wherein political authority, while aware of the necessity of adhering to Islamic norms in the law-making process, is always keen on having a final say in deciding the law of the state in its entirety. Occasionally, the state might scarify some of these norms for whatever political reasons, but at least would always endeavor to flavor the law-making process by an Islamic cover-up.

\section{Modern constitutional structures require participation of many actors in the lawmaking process}

Nowadays, the complications of modern state constitutional structure, even within those states that proclaim that they are Islamic, requires the participation of a number of actors in the law-making process. Indeed, if a single actor handles this mission, it becomes clear who is in charge. But when multiple actors exist, as the case usually is, the potential of struggle over religious authority becomes obvious.

With its unique complex composition of both certain and uncertain norms, the journey to identify and realize the law in a Muslim country turns out to be demanding as well as challenging. Unlike definitive norms of Islamic law that all jurists honor, what makes it devastating is the fact that most of the rulings of Islamic law do not belong to the definitive, but rather to the indefinite areas wherein fiqh usually maneuvers amongst various interpretations, of fundamental differences to each other, in an attempt to reveal God's law. Allowing various actors to play a role, at the same time, to realize the law and bring it up to the level of enforcement, would certainly pave the way before different juristic schools, not only to manifest their differences, but eventually to collide with each other in a 
manner that will most likely negatively affect legal certainty and expose societal harmony to real risk.

\section{The role of the religious authority in Egypt: From supremacy to declination}

Herein, the case of modern Egypt presents an interesting example showing us how the power of the religious authority gradually declined dramatically over time in the law-making process in favor of other irreligious institutions or the state at large. The Muslim conquests reached Egypt as early as the year $641 \mathrm{CE}$ and led to the termination of the Byzantine rule and beginning of the Islamic rule under Amr ibn al-As. Since then, Egypt remained a state affiliated with the subsequent Islamic empires until its official separation from the last one of them, the Othman Empire, in 1914, before the demission of that empire in 1923. The harbingers of separation and autonomy, however, began earlier following the commencement of the rule of Mohammad Ali's family in 1805 .

Throughout the Islamic empires' rule, there had been ups and downs as far as the empire-controlled state affairs, including defining Islamic sharia and law. However, with the deterioration of the Othman power on one hand, and continuing upsurge of Mohammad Ali's power on the other, many improvements of western style to state bureaucracy had been initiated and somewhat led to indispensable changes in that role religion and religious institutions had traditionally played in the land. The tradition in Muslim societies is for competent religious figures and institutions to inform the rulers on matters of Islamic sharia and law. Therefore, by the 19th century onwards traditional religious institutions embraced al-Azhar, with a long history dated back to the 10th century, and the state Muftis, who are an innovation of the 19th century and always associated themselves with the state throughout the time. In addition, among the important actors were sharia judges who represented an integral part of the ruling system in the Islamic era until sharia courts were finally abolished in the year 1955 . The contribution of these actors to the law-making process was substantial, but with the changes in the governing system the new rulers introduced, their role in this area began to decrease. As a result, today, and with all changes and developments to the governance system throughout time that turned it to be more western based than Islamic, one may question whether these institutions have maintained a role to play? And if so, how influential this role would be? In fact, the moral weight of that role is a constant feature of any given Islamic society wherein a tendency to observe the religious law and abide by it always remains valid at all times. But 
when the modern state penetrates this area, for obvious political reasons that largely have to do with the existing constitutional structure, it is very unlikely for religious institutions to remain powerful when it comes to deciding the law of the land. At modern times, even within states who proclaim to be Islamic, the authority to decide the law does not solely rest in the hands of whatever religious institutions they might have. No matter how the religious institution is involved, the reality continues to be that the state, as a political power, remains to be the final authority that controls the law.

\section{Constitutional deference to Islamic sharia in Egypt responding to a 20th century's regional call}

As we will be discussing later in this chapter, since the 20th century, Egypt has followed a trend widely existing in the vast majority of Arab states, by proclaiming deference to the principles of the Islamic sharia within its successive constitutional documents, that is derived far more from European than Islamic legal traditions, with a formula that varied chronologically from one constitution to the other. Article 2 of the 1971 Constitution, as amended in 1980, followed by subsequent constitutional documents, including the existing 2014 Constitution, positioned Islamic sharia at the apex of legal norms. It explicitly provided for Islam as the religion of the state and Islamic sharia to be the principal source of legislation. At the comparative level, it is not uncommon to argue that the constitution itself is bound by prior or higher principles. Therefore, despite the fact that the constitution, the supreme law of the land, which makes other laws possible, and always presents itself as the fundamental law of the state and the expression of the will of a sovereign people; the reference to the Islamic sharia, implies the existence of a higher or prior law. This could mean that the sharia is adopted not only to guide interpretation processes, but also to supersede all other legal rules, including, perhaps, the constitution itself. And this is not merely a theoretical or abstract argument; much contentious political debate, and sometimes violence, has centered on the proper relationship between the legal order devised by human beings and that derived from divine sources. 


\section{Egyptian society signifies high-level of religiosity}

As the case is settled in many other Muslim dominated societies, the level of religiosity in Egyptian public life is high, and Egyptians generally cast their understanding of relations not only between individuals and God, but also among individuals themselves, in terms of religious concepts and obligations. The dominance of Islam in Egyptian society, with perhaps over ninety percent of the society professing to be Muslims, is acknowledged in all Egyptian constitutional texts in the 20th century. Nevertheless, those same constitutional documents insist that non-Muslim Egyptians are to be accorded the same status as Muslim Egyptian citizens. Such provisions can be, and are, understood not as antithetical to a sharia-based order, but as intrinsic to it, founded on provisions for freedom of religion and belief.

As a result, the political order in Egypt has presented itself as Islamic since the arrival of Islam to the country almost fourteen hundred years ago. With the majority of the Egyptian population turning to Islam, the sharia became the accepted basis, not only for governance, but also for social relations. While total obeisance to sharia principles was probably never the norm, the Islamic sharia still held ideological dominance until the late 19th century.

\section{Gradual declination of the applicability of the sharia}

Since that time, the 19th century, and with the progressive improvements to the governance systems presented by the rulers, new and comprehensive law codes, derived mainly from the European codes, began to be adopted parallel to similar governance system developments in the Ottoman Empire and its affiliated Arab countries. The result was to restrict the applicability of sharia-based legal principles in almost all fields, with the exception of the family status issues field, in which Islamic sharia principles continued to prevail. Non-Muslims continued to be governed by their own religious rules, a practice itself in accordance with Islamic principles guaranteeing followers of divine revelations, Christians and Jews, the right to apply their own religious laws.

In reality, the process of transformation has left its impact on these countries since then up until now. Today, legislation in most Arab countries, including Egypt, is generally not drawn from the Islamic sharia, but is grounded in those European codes. For instance, civil and criminal codes now applied in Egypt are ultimately derived from French codes 
and have in turn inspired a multiplicity of the substantive and procedural legal rules in the region. This state of affairs has become increasingly controversial in recent years, not only in Egypt, but throughout the Arab world. Increasing calls are heard from various Islamic movements for an Islamic State based on sharia. Such calls seem to strike a strong resonance in predominantly Muslim societies, and Egypt has seen a remarkably intellectual ferment concerning this issue. It is not surprising, therefore, that Egypt has, along with many other Arab countries, moved to attempt to adopt a sharia-based constitutionalism.

\section{Islamic states with secular practices}

Despite this trend and despite the fact that the constitutions of Islamic countries, to which the Constitution of Egypt belongs, ensure their religious nature, the recent movement to accommodate religion has not yet resulted in a noticeable change to the system of government and the practices of public authorities in these countries, which remain essentially secular. This, in fact, presents a conflict between state and religion in Islamic countries that these countries are now attempting to address in various ways. The struggles that have gained most international attention have even taken violent form. Yet a constitutional and legal struggle, occurring far less in the especially western public eye, has also led to a remarkable effort to diminish the gap between law and governance on one hand and sharia derived principles and practices on the other.

\section{Article 2 of the Constitution and the supremacy of the sharia}

As we have highlighted earlier in this article, in 1971, Egypt joined those Arab and Islamic countries who explicitly provide for a link between the Islamic sharia and legislation. That year, the country received a "permanent" constitution to replace the avowedly temporary documents of the Nasser years. Unlike preceding constitutional documents, Article 2 of the 1971 Constitution went beyond mere declaration of Islam as the religion of the state as such a formula was no longer deemed adequate. It more ambitiously described the principles of the Islamic sharia as "a principal source of legislation." Arguments in favor of still stronger provisions were rejected for the moment as reflected in the minutes of the Preparatory Committee for drafting the Constitution. Yet the proponents 
of a stronger Article 2 won a delayed victory as the Constitution was amended nine years later to make the principles of the Islamic sharia "the" principal source of legislation. As amended, Article 2 of the 1971 Constitution proclaimed: "Islam is the religion of the State, Arabic is its official language and the principles of the Islamic sharia are the principal source of legislation". Same language has been adopted in the following constitutional documents, including, both the 2012 Constitution and the 2014 Constitution.

\section{Many actors are there, but are they influential?}

Today, in addition to the traditional known religious actors, other new actors have already joined the track. Al-Azhar, the state Mufti and the Ministry of Religious Affairs sit at the frontline among religious competing actors. Despite of their autonomy from each other, they are all considered partners in leading a serious movement towards renewing religious discourse in order to promote the image of Islam in contemporary world and present it in its true sense as a religion of peace and tolerance. Other, official and unofficial, actors include, but not limited to, the media, both state supervised media and private ones; educational intuitions wherein religious education is mandatory throughout pre-university level; prayer places and family law courts as family law issues are generally governed by religious rules. There is no doubt that some influence of these institutions is present whenever a religious issue is brought to the attention of the people. Though al-Azhar, the state Mufti and the Ministry of Religious Affairs all have official capacity, and eventually seen as loyal to the régime, their engagement or contribution to any public or religious debate could differ. While the Ministry is understandably serving as the mouthpiece of the government, both al-Azhar and the state Mufti tend to portray themselves as the religious conscience of the land, especially al-Azhar after being accorded a constitutional status by virtue of Article 4 of the 2012 Constitution, followed by Article 7 of the 2014 Constitution, that considers it an autonomous scientific Islamic institution and the predominant reference in religious sciences and Islamic affairs. For that reason, both al-Azhar and the state Mufti are likely keen not to be observed as subservient to the political authority; hence are usually eager to assert their autonomy before the public; such autonomy that is actually guaranteed by virtue of state laws and regulations organizing these institutions and specifying their mandate. 


\section{The final authority in deciding Islamic norms does not belong to the religious actors}

Despite the co-existence of these multiple actors by each other, and considering whatever contributions they might be able to make in any religious debate; the reality is that any role played by any of these institutions, either official or unofficial, remains within the consultation or advisory side of the process and is not, per se, enforceable. Other than the moral value the fatwas or other religious pronouncements declared by these institutions may hold, they are all legally unbinding and cannot be enforced without appropriate enforcing mechanism. To be legally enforced, they have to be embodied within legislation or ordained by a court decision. This ultimately means that the final authority in deciding enforceable Islamic norms does not belong to the religious institutions, no matter how societally influential they are; rather, this authority remains within the hands of the legislature, which is Parliament, together with the executive branch of the Government whenever this branch is accorded a constitutional mandate to exercise legislative power. The Supreme Constitutional Court (SCC) is also considered a final authority and arbitrator in deciding what the law, including Islamic law, is. Through exercising exclusively, the power of judicial review in constitutional issues, the SCC articulates and gives the final true and binding meaning to the constitutional norms guaranteed by the Egyptian Constitution, including Islamic sharia norms. This has been the case since the Court was first founded back in 1969 up until now by virtue of its establishing legislation as well as constitutional commands.

\section{The rule of the Muslim Brotherhood: An unsuccessful attempt to raise the power of the clergies}

Another interesting development to highlight, however, had taken place right after the collapse of Mubarak regime in 2011, and the arrival of Mursi to power the following year. The Muslim Brotherhood, with their outrageous animosity towards the SCC and its liberal interpretation methodology in Islamic sharia, found it to be a golden opportunity to use their 2012 Constitution as a tool by which they would raise the power of the clergy; hence, limit the power of the SCC. Contrary to the SCC's methodology, their vision was that law should always be measured for consistency with legal principles found in the four traditional sources of sunni Islamic law: the Quran, sunna, qiyas, and ijma, then interpreted in 
a manner informed by a study of texts considered exemplary within the sunni tradition. Among these texts, must be the traditional sunni texts dealing with the subject of usul al-fiqh and qawa'id fiqhiyya. In order to implement this vision, they had to introduce two new provisions to that Constitution, Article 4 and Article 219. In Article 4, they accorded al-Azhar a constitutional status as an autonomous Islamic institution in charge of spreading Islamic discoursing, religious sciences and Arabic language over Egypt and throughout the world. They also required that opinion of al-Azhar's Body of Senior Religious Scholars (Hay'at Kubar al-Ulama') should be taken on Islamic sharia affairs. Then in order to foster their attempt, they introduced Article 219 by using an ambiguous language and some technical terms rarely used outside of scholarly circles that read: "The principles of the Islamic sharia include its adilla kulliya, qawa'id usuli and qawa'id fiqhiyya and the sources considered by the sunni madhhabs."

Had the core of these two new constitutional articles been actually implemented, they would have definitely changed the mode in which the law is argued and how its legitimacy is evaluated, and also as to determining those who are competent to be in charge of carrying out this mission. But as Mursi's constitution was only there for just a very short period of time, these provisions were never tested or given real substantive effect in the law-making process; hence, no major changes to the already established theory of the law-making and interpretation was practically introduced. Today, in the existing 2014 Constitution, while Article 7 continues to recognize the role of al-Azhar as an autonomous Islamic institution and principal reference in religious sciences and Islamic affairs, the arrangements embodied in Article 219 of the 2012 Constitution have now ceased to exist and are no longer there.

\section{How the law is finally articulated? The supremacy of the constitutional jurisdiction as to defining Islamic law}

Today in Egypt, and throughout the past few decades, the country's Supreme Constitutional Court has found itself in the forefront of the battle to decide what Islamic law is by giving life to the very general wording of Article 2 since it was amended in the 1980 up until this moment under the 2014 Constitution. The Court, as a secular, not religious, institution adopted a distinctive modernist approach that acknowledges scholars and their traditions. Yet at the same time, occasionally, the Court's approach has the flexibility to ignore the views of the traditional scholars if the Court considers them no longer compatible with modern life exigencies 
and the needs of the people. De novo approach has always been the Court's practice while adjudicating Article 2 cases. The Court interpreted Islamic law using its own distinctive, somewhat idiosyncratic, version of modernist reasoning. The Court concludes that state law would be measured against two different types of Islamic principles: The first were those clearly and explicitly announced in the Quran and that limited number of hadiths whose authenticity was not merely presumptively true, but was entirely beyond doubt - which the SCC found very few in number. The second were overarching principles that could be induced from a study of the scriptures as a whole. Among these induced principles, some of the most important were principles of utility and justice -- and the Court did not automatically defer to traditional sunni scholar's understandings of these terms. Rather it measured laws against its own quite liberal understandings, often arriving at results inconsistent with traditional pre-modern sunni interpretations of Islamic law.

In carrying out this methodology, the fulfillment of public welfare, preservation of the foundation goals of the sharia (religion, life, lineage, intellect and property) and consideration of the changing human needs, in terms of time and place, have always been at the center of the Court's concern. Today, there is no doubt that the understandings and rulings of the Court, the highest judicial institution in the country and one of the most influential in the Arab world, has helped determining the extent to which the Islamic sharia serves as a sound base for a constitutional democracy in the contemporary world.

\section{Three major foundations in deciding Islamic norms}

In practice, the SCC has established three foundations in developing its jurisprudence and binding interpretation of the meaning of Islamic sharia principles within a constitutional framework. The first of these is that Article 2, together with all other Articles in the Constitution, forms a unified organic unit. The second is that the constitutional obligation imposed upon the legislature to adhere to Islamic sharia, in accordance with Article 2, is prospective and not retrospective in nature. The third base asserts that the application of sharia principles in constitutional litigation must be based on a distinction between its definitive and indefinite sources. Though these foundations were established under the 1971 Constitution, they have remained valid all through up until the present time due to the Court's continuing uniform constitutional understanding of the role of Islamic sharia in society since the amendment of the 1971 Constitution in 1980. 
First: The constitution should be looked at as a single, uniform organic unit. The unity of the constitution has always been a prevailing theme running throughout the jurisprudence of the SCC. This view of the constitution leads the SCC to deny the supremacy of a particular constitutional text over the rest of the constitution. Instead, the Court has insisted that constitutional provisions do not collide with each other, but collectively form an interrelated, organic unit, accomplished by coordinated methods of construction that conserve society-oriented values. Constitutional provisions are to be understood as a coherent, harmonized body of rules, reconciled and brought together to the extent that none of them is to be viewed as standing in isolation from the other (Constitutional Case No. 23 of the Fifteenth Judicial Year, decided on 5 February 1994).

This rule, undoubtedly, extends to Article 2 of the Constitution and, therefore, the Islamic sharia should always be perceived in a way that assures its harmony with other constitutional commands. Article 2 can therefore not be taken to undermine the rest of the text; instead, the various provision of the Egyptian Constitution must be viewed together.

Second: The application of Article 2 has a prospective nature. Ever since Article 2 of the 1971 Constitution was amended in 1980 to elevate the principles of Islamic sharia from "a" principal source to "the" principal source of legislation, the issue of its chorological applicability, and whether it could be applied retroactively, had to be addressed by the SCC. Since 1985, Article 2 jurisprudence of the SCC has been established on the premise that the constitutional requirement that all legislation must be consistent with the principles of Islamic sharia was prospective only from the date of adoption of the constitutional amendment, that is May 22,1980 ; hence, the binding constitutional obligation to derive legislation from the principles of Islamic sharia only applies to the future. Legislation passed before the 1980's amendment of Article 2, cannot therefore be contested on constitutional grounds as a violation of Islamic sharia. This is because the true purpose of the amendment was to limit the legislative power of the legislature, which logically could only be exercised for future legislation (Constitutional Case 20 for the First Judicial Year).

The SCC, however, held that Article 2 is a limitation on the legislature, which must determine for itself whether legislation adopted before May 22, 1980 is consistent with the Islamic sharia. By deciding so, the court did not free the legislature of any responsibility for ensuring that pre-1980 legislation conformed to sharia principles. On the contrary, it imposed a political responsibility on the legislature to initiate new legislation to amend such texts where they are clearly in contradiction with principles of 
Islamic sharia. Both existing and future legislation, eventually, have to be consistent with Islamic sharia.

Third: Establishing a distinction within Islamic sharia between definitive and indefinite norms. The final and most complex principle developed by the SCC involves the nature of sharia principles. In essence, the SCC has held that sharia-based norms have different value: such norms are either definitive or indefinite. In defining Islamic sharia principles the court relied on an unshaken chain of precedents which clearly stated that definitive principles are Islamic norms which are not debatable, either with respect to their source or the precise meaning. Such definitive norms must be applied. All other Islamic norms are indefinite in that they are susceptible to different interpretations and-due to their nature-changeable in response to the exigencies of time, place and circumstances. Such flexibility reflects not a defect in the sharia in the Court's eyes, but a strength, because it allows the principles to be adapted to changing realities and ensures their continued vitality and elasticity. Only in the realm of Islamic indefinite norms may the legislature intervene to regulate matters of common concern and achieve related interests. It must do so in consistence with basic Islamic norms, the aim of which is the preservation of religion, reason, honor, property, and the body. The legislature might develop different practical solutions to satisfy variable societal needs. The SCC regards the bulk of Islamic indefinite norms as highly developed, intrinsically in harmony with changeable circumstances, repulsive of rigidity, and incompatible with absoluteness and firmness. In no way may an Islamic indefinite norm, which is fading-whether due to time, place, or pertinent situations-be mandated by the Court or the Constitution (Constitutional Case 8 of the Eighteenth Judicial Year, decided on May 18, 1996).

The SCC jurisprudence, has always upheld this distinction between definitive or peremptory provisions or norms of the sharia on the one hand, and its indefinite or non-peremptory provisions or norms on the other. After the 1980 Amendment of the Constitution, all newly enacted legislation must adhere to definitive or peremptory norms of Islamic sharia. Where no such definitive norm exists, the legislature should adhere to the ijtihad most favorable for the people, selected from among indefinite or non-peremptory norms of the Islamic sharia.

Thus, ijtihad governs the process of determining the best applicable rule within indefinite norms. Ijtibad within the non-peremptory provisions in sharia is a process of reasoning to deduce practical rules to regulate the life of the people and achieve their interest. It should, therefore, cope with the context of events prevailing at the time. While the legislature might choose a specific interpretation as the basis of legislation, it cannot give 
that interpretation the status of binding doctrine, except on those who accept it. The court's jurisprudence is based on viewing such multiple possibilities as a sign of divine mercy that encourages Muslims to think and discuss, diminishing the possibility of human error. The existence of indefinite norms is also taken to ensure that the Islamic sharia always develops and displays flexibility to accept ijtihad of responsible people to achieve the public interest.

When invoking Islamic sharia, the court, therefore, first searches for peremptory norms, and if finding none, looks at ijtibad that is consistent with the challenged legislation and achieving the interest of the people. Then, the court examines the purposes of this legislation. And at the outset, the Court determines whether the challenged provision is consistent with the interests of the people or not, and decides its constitutionality based on this conclusion.

\section{Conclusion: The role of the state, and that of the SCC, supersede the role of the religious actors in defining the law}

The current situation in Egypt suggests that existing religious institutions, both official and unofficial, do not have a considerable input in the lawmaking process. Though they undoubtedly might sometimes heat up the debate and have an indirect role informing the law makers of Islamic norms while preparing legislation, still their role cannot be always deemed of having a great influence in this process at all times. The state, through the legislature, remains the sole actor in charge of pronouncing the state's law, including Islamic law. The SCC, through exercising the power of judicial review in constitutional issues solely and exclusively is there not to legislate, but rather to monitor the legislature, within check-and-balance arrangements, in order to make sure that state law, including Islamic law, is consistent with the constitutional commands which include Islamic sharia principles themselves as the principal source of legislation. Indeed, this positions the SCC as the final arbitrator and elevates it to the higher status in shaping up Islamic norms in Modern Egypt; a mandate that the SCC has always undertaken seriously, liberally and progressively throughout the years. 


\section{References}

Ahkam wa Qararat Almahkama Akdostoria Alolya. Volumes of Rulings and Decisions of the Supreme Conational Court of Egypt from 1985-2016.

Al-dasatir al-misriyya 1805-1971: Nusus wa-tahlil. [The Egyptian Constitutions 1805-1971: Texts and Analysis]. Cairo: Markaz al-tanzim wa-l-mikrufilm, 1976.

Brown, Nathan J. 2011. "Post-Revolutionary Al-Azhar". The Carnegie Papers, September.

Brown, Nathan J. and Adel Omar Sherif. 2004. "Inscribing the Islamic Shari'a in the Arab Constitutional Law." In: Islamic Law and the Challenges of Modernity, edited by Yvonne Yazbeck Haddad and Barbara Freyer Stowasser. Walnut Creek, USA: Altamira Press.

Cole, Juan R. I. 1993. Colonialism and Revolution in the Middle East: Social and Cultural Origins of Egypt's 'Urabi Movement. Princeton: Princeton University Press.

Lombardi, Clark and Nathan J. Brown. 2012. "Islam in Egypt's New Constitution." Foreign Policy, December: 13.

Minutes of the Preparatory Committee for Drafting the Constitution for the Arab Republic of Egypt, 1971.

Omar Sherif, Adel. 1998/1999. "An Overview of the Egyptian Judicial System and its History." Yearbook of Islamic and Middle Eastern Law 5: 3-28.

Parolin, Gianluca P. 2015. "Shall We Ask Al-Azhar? Maybe Not." Middle East Law and Governance 7: 212-235.

Scholch, Alexander. 1981. Egypt for the Egyptians! The Socio-political Crisis in Egypt 1878-1882. London: Ithaca Press. 
